\title{
Influence of Land Use and Rainfall on Carbon Stock Dynamics for Oil Palm and Rubber
}

\author{
Oktanindita Priambodo1, Hariyadi', Suwarto', I Putu Santikayasa² \\ ${ }^{1}$ Department of Agronomy and Horticulture, Faculty of Agriculture, IPB University, Dramaga Campus, Bogor, Indonesia \\ 16680 \\ ${ }^{2}$ Department of Geophysics and Meteorology, Faculty of Mathematics and Natural Sciences, IPB University, Dramaga Campus, \\ Bogor, Indonesia 16680
}

\section{ARTICLE INFO}

\section{Received}

11 May 2020

\section{Revised}

2 June 2020

\section{Accepted for Publication \\ 13 October 2020}

\section{Published}

14 December 2020

doi: 10.29244/j.agromet.34.2.121-128

\section{Correspondence:}

Oktanindita Priambodo

Study Program of Agronomy and Horticulture, Faculty of Agriculture, IPB University, Dramaga Campus, Bogor, Indonesia

16680

Email:

oktaninditapriambodo@gmail.com

\begin{abstract}
A B S T R A C T
The expansion of agricultural commodities including oil palm plantations potentially causes an increase of greenhouse gas emissions by amplifying carbon dioxide $\left(\mathrm{CO}_{2}\right)$ in the atmosphere. In the long term, this amplification will alter climate change. However, oil palm also has the potency to reduce greenhouse gas emissions by absorbing $\mathrm{CO}_{2}$ through photosynthesis. This study aims to determine the carbon stock that can be absorbed by oil palm and rubber plants, and to determine the relationship of rainfall with carbon stock in oil palm plants. The study used satellite image data based on Landsat and combined with rainfall data from near Perbaungan District, North Sumatra. Three Landsat data (acquisition date: (i) 12 February 2000, (ii) 8 March 2009, and (iii) 11 August 2019) were processed to estimate carbon stock. The procedure for estimating carbon stock was as follows: determining the sample and digitizing the sampling points, converting the digital value of the numbers into the spectral spectrum, calculating the albedo values, calculating the long-wave and short-wave radiations, computing biomass, and the absorbed carbon stock. The results showed that the carbon stock in oil palm was greater than that of rubber plants as oil palm has a greater biomass. The greater the plant biomass, the bigger the carbon stock absorbed. Further, the findings revealed that rainfall in dry season has a contribution to carbon stock in oil palm and rubber. The higher the total rainfall during dry season will increase the absorbed carbon stocks.
\end{abstract}

\section{KEYWORDS}

biomass, changes, development, growth, land cover

\section{INTRODUCTION}

Oil palm and rubber plants are the most important foreign exchange in Indonesia, and the most profitable crops for smallholder and plantation companies. Their high economic attractiveness leads them growing and expanding rapidly in Indonesia. For instance, the expansion of oil palm area reached about $14,030,600$ ha (BPS, 2018a), while the area of rubber was about 3,549,044 ha (BPS, 2018b). The expansion of both crops has altered land-uses in Indonesia, which influenced carbon dynamics in land (Finstad et al., 2020;
Toru and Kibret, 2019) leading to an increased carbon dioxide in atmosphere (Arneth et al., 2017; Burton et al., 2017; Ishikura et al., 2018). In addition, land-use change has altered hydrological processes by decreasing infiltration in their oil palm ecosystem, which declines water availability (Guzha et al., 2018; Manoli et al., 2018).

Land-use change associated carbon emission is seriously environmental issues. Carbon in the atmosphere may be absorbed by oil palm through its growth and development (Cook et al., 2018; Meijide et al., 2020). Climate is one of the factors determine oil palm's 
growth, development, and crop production (Paterson et al., 2015). Rainfall is the most climate variables that affects oil palm. For instance, rainfall determines nutrient dynamics and leaching in oil palm ecosystem (Darlita et al., 2017). The higher rainfall is, the more nutrient leaching occurs in soil, especially for nitrogen nutrients. Highly leaching of nitrogen affects growth and development of oil palm in particular for flowering process (Mohidin et al., 2019).

Nitrogen nutrient plays an important role in vegetative growth and biochemical processes of oil palm, including in the process of photosynthesis. Nitrogen itself is an important constituent of chlorophyll. The process of photosynthesis plays a major role in plant growth and development to build plant biomass (Behera et al., 2017). The high biomass represents highly absorbed carbon in oil palm (Rachdian and Setiawan, 2018). According to Carlson et al., (2012), more than $75 \%$ of gross carbon emissions from oil palm were sourced from clearing of above ground biomass in intact, logged, and secondary forests on mineral soils. Peatland deforestation and draining for oil palm contributed relatively few gross emissions $(10 \%$ and $11 \%$, respectively). The emission factor for peat oxidation for oil palm plantations operating on peat soils was $43 \mathrm{Mg}$ $\mathrm{CO}_{2}$ ha $^{-1}$ years ${ }^{-1}$, while the greenhouse gases emission factors for peat fires, when establishing oil palm plantations in swamp forest based on above ground carbon (AGC) estimates was $333 \mathrm{Mg} \mathrm{CO}$ ha $^{-1}$ and swamp

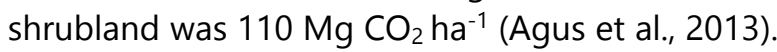

Oil palm is an annual plant, which absorbs $\mathrm{CO}_{2}$ through photosynthesis. Through photosynthesis, $\mathrm{CO}_{2}$ is absorbed and converted by plants into organic carbon in the form of biomass (Kii et al., 2020). Current estimate indicated that absorbed $\mathrm{CO}_{2}$ by oil palm that was converted into biomass was 6.1 ton $\mathrm{C} \mathrm{ha}^{-1}$ year ${ }^{-1}$ (Pulhin et al., 2014). Other study reported that biomass of oil palm was $223.68 \mathrm{kgCtree}^{-1}$ or equivalent to 28.63 ton $\mathrm{C} \mathrm{ha}^{-1}$ (Siswoko et al., 2017), which is equal to 104.97 ton $\mathrm{CO}_{2} \mathrm{ha}^{-1}$. Previous researches showed that oil palm has a potency to absorb carbon (Austin et al., 2017; Besar et al., 2020; Khoon et al., 2019; Kii et al., 2020). In order to utilize the function of oil palm plants as carbon sinks, it is necessary to quantify how much carbon can be absorbed and stored in oil palm ecosystem. Therefore, the study aims to identify how much absorbed carbon under oil palm and rubber plants, and to quantify the relationship between rainfall and absorbed carbon in oil palm and rubber.

\section{RESEARCH METHODS}

\section{Study Area}

This study was carried out in oil palm plantation in North Sumatra. We chose Kebun Melati as location for sampling activities. Kebun Melati is located in Perbaungan District, Serdang Bedagai Regency, North Sumatra. Typically, the soil types found in the plantation were: Typic Hapludalf, Typic Ochraaquult, and Acric Tropaquent. Geologically, this area was classified into a quaternary formation with Alluvium as the parent material. The area receives rainfall as much of $1,707 \mathrm{~mm}$ annually. The area of plantation was 24,953.31 ha, which was divided into three blocks (called as afdelling). In 2000, the area was firstly planted with rubber. Then, since 2001 oil palm replaced the rubber. The planting distance for rubber was $4 \times 5$ meters, whereas the planting distance of oil palm was $9 \times 9$ meters.

\section{Data and Analysis}

Data collection was carried out in Kebun Melati, Perbaungan District, North Sumatra from August to December 2019. We sampled 50 oil palm plants to collect diameter of breast height (DBH) and height of plants. Each sample location was marked using global positioning system (GPS) to obtain its coordinate point.

Totally, there were three Landsat images used in this study. The two images were from Landsat 5 (date acquisition: 12 February 2000 and 8 March 2009, path/row 129/58), and one image from Landsat 8 (date acquisition: 11 August 2019, path/row 129/58). In addition to image data, rainfall data representing the year of Landsat data used were collected. For 2000, we collected monthly rainfall data from August 1998 - July 2000, for 2009 we used rainfall data from August 2007 - July 2009. Then for 2019, rainfall data from August 2017 - July 2019 were used. The rainfall data was based on NOAA products, which is available online from www7.ncdc.noaa.gov/CDO/cdo. All images and rainfall data were cropped with Kebun Melati coordinate $\left(3.473^{\circ}-3.565^{\circ} \mathrm{N}\right.$ and $\left.98.011^{\circ}-99.011^{\circ} \mathrm{E}\right)$.

\section{Carbon Stock Estimation Based on Satellite Images}

\section{Sampling points}

There were 50 sampling points in Kebun Melati to derive carbon biomass. Based on Landsat satellite images, the land use in 2000 was rubber plants, then the land use was oil palm in 2009 and 2019.

\section{Radiometric correction}

There are two types of atmospheric correction for satellite image data, both in Landsat 5 and Landsat 8, namely top of atmosphere correction (ToA) and bottom of atmosphere correction (BoA). ToA is usually used to eliminate radiometric distortion due to the sun's position. ToA correction is carried out through radiometric calibration by converting the digital number value to a reflectance or radian value (Dewanti and Sari, 2017). Meanwhile, BoA correction is obtained from atmospheric correction. Spectral radiation is the range 
of radiation values reflected by the object as shown in Equation (1) (Avdan and Jovanovska, 2016):

$$
L_{\lambda}=G_{\text {rescale }} \times Q_{\text {cal }}+B_{\text {rescale }}
$$

$\mathrm{L}_{\lambda}$ is spectral radiance value $\left(\mathrm{W} \mathrm{m^{-2 }} \mathrm{sr}^{-1} \mu \mathrm{m}^{-1}\right), \mathrm{G}_{\text {rescale }}$ is rescaling factors for each band $\left(\mathrm{W} \mathrm{m}^{-2} \mathrm{sr}^{-1} \mu \mathrm{m}^{-1}\right), \mathrm{Q}_{\text {cal }}$ is pixel value in the image digital number (DN), and $B_{\text {rescale }}$ is rescaling factors $\left(\mathrm{W} \mathrm{m} \mathrm{m}^{-2} \mathrm{sr}^{-1} \mu \mathrm{m}^{-1}\right)$ for each channel.

\section{Calculation of albedo}

Albedo is the ratio of reflected shortwave radiation to the incoming solar radiation (Gul et al., 2018). The albedo is influenced by the physical properties of the Earth's surface, for instance color of the surface. Other factor influencing albedo is the sun's zenith angle. Under the same conditions, the albedo will decrease as the sun's zenith angle increases. The albedo was estimated using Equation (2) (Uttaruk and Laosuwan, 2016):

$$
\alpha=\frac{3.14 \times L_{\lambda} \times d^{2}}{E S U N_{\lambda} \times \cos \theta_{S}}
$$

$\alpha$ is albedo, $L_{\lambda}$ is a spectral radiation $\left(\mathrm{W} \mathrm{m} \mathrm{m}^{-2} \mathrm{sr}^{-1} \mu \mathrm{m}^{-1}\right)$ derived from Equation (1), $d$ is earth-sun distance (astronomical units), ESUN ${ }_{\lambda}$ is exoatmosphere mean of solar radiation $\left(\mathrm{W} \mathrm{m}^{-2} \mu \mathrm{m}^{-1}\right)$, and $\theta_{\mathrm{s}}$ is sun's zenith angle (degree).

\section{Calculation of outgoing longwave radiation}

The outgoing longwave radiation is an electromagnetic radiation with wavelengths between 3.0 and $100 \mu \mathrm{m}$, which is emitted from the earth into outer space in the form of thermal radiation. This typical radiation involves the processes of absorption, scattering and emission from atmospheric gases, aerosols, clouds, and Earth surfaces. The outgoing longwave radiation (Rsout) is calculated with Equation (3) (USGS, 2016):

$$
R s_{\text {out }}=\varepsilon \sigma T s^{4}
$$

$\varepsilon$ is emissivity, Ts is temperature of surface $(\mathrm{K})$, and $\sigma$ is Stefan-Boltzman constant $\left(5.67 \times 10^{-8} \mathrm{~W} \mathrm{~m}^{-2} \mathrm{~K}^{-4}\right)$.

\section{Calculation of incoming shortwave radiation}

The incoming shortwave radiation was estimated based on albedo value. The value of shortwave radiation received by the surface can be obtained by Equation (4) (USGS, 2016):

$$
R s_{\text {in }}=\frac{R s_{\text {out }}}{\alpha}
$$

$R s_{\text {in }}$ is an incoming shortwave radiation to the earth surface, $R s_{\text {out }}$ is an outgoing shortwave radiation, and $\alpha$ is albedo value.

\section{Calculation of leaf area index (LAI)}

In the study, LAI value was required to derive biomass. To obtain LAI, we estimated the greenness of vegetation by normalized difference vegetation index (NDVI). NDVI is a standard method to estimate chloro- phyll content in vegetation (Amliana et al., 2016). Estimation of NDVI is obtained using Equation (5) (e.g. Cao et al., 2018; Chu et al., 2019; Duan et al., 2017):

$$
N D V I=\frac{N I R-R E D}{N I R+R E D}
$$

NIR is near infrared band (band 3), RED represent red spectral of band 4 from Landsat image. NDVI ranges from -1 to 1 . A high index value indicates that the vegetation is dense. The estimation of LAI value from the NDVI value is obtained using Equation (6) (Twele et al., 2008):

$$
L A I=-0.392+(11.543 \times N D V I)
$$

\section{Biomass estimation}

The potency of biomass is determined by the radiation use efficiency $(\varepsilon)$ and the intercepted radiation ( $Q_{\text {int }}$ ). Equation (7) describes the calculation of biomass based on Beer's law approach.

$$
B b=E \times Q_{\text {int }}=E\left(1-e^{-k L A I}\right) R s_{\text {in }}
$$

$B b$ is potential biomass production $\left(\mathrm{kg} \mathrm{ha}^{-1}\right.$ day $\left.^{-1}\right), E$ is radiation use efficiency $\left(\mathrm{kg} \mathrm{MJ}^{-1}\right), Q_{\text {int }}$ is interception radiation ( $\mathrm{MJ} \mathrm{m}^{-2}$ ), and $k$ is extinction coefficient. The value of radiation use efficiency for oil palm is about 1.3 $\mathrm{g} \mathrm{MJ}^{-1}$ while the extinction coefficient value is 0.46 (Perez, 2017).

\section{Estimated carbon stock}

In general, plants absorb carbon dioxide for photosynthesis, then convert it into organic carbon in the form of biomass. The carbon content in biomass at a certain time is known as carbon stock (Rahaju, 2008; Srinivas and Sundarapandian, 2019). The carbon stock ( $C_{\text {est }}$, ton ha-1) then is calculated by Equation (8) (Supriadi, 2012):

$$
C_{\text {est }}=B b \times C \text {.Organic }
$$

$B b$ is total biomass (ton plant ${ }^{-1}$ ) and C.Organic is $47 \%$ (Azham, 2015) for oil palm trees, while for rubber plants was 46\% (Supriadi, 2012).

\section{Validation of Carbon Stocks}

We sampled 50 oil palm plants in 2019 from three blocks (called as afdelling) in Kebun Melati. In afdelling 1 and 2, we collected samples from oil palm plants, which was planted on 2001, 2011, and 2013. For afdelling 3 , there were four year of planting namely 2001, 2008, 2012, and 2013. In each sample we measured the diameter of breast height $(\mathrm{cm})$ and height of oil palm plant $(\mathrm{m})$. The dry biomass of oil palm then estimated based on allometric approach (Yulianto et al., 2016) as presented in Equation (9).

$$
B k=0.002382 . D^{23385} \cdot H^{0.9411}
$$

$B k$ is tree dry biomass (ton tree ${ }^{-1}$ ), $D$ is diameter of the stem with midrib at breast height measured as perpendicular to the stem $(\mathrm{cm})$, and $H$ is oil palm plant free 
height $(m)$. The actual biomass is then calculated with Equation (10).

$$
B p=\frac{\sum n B k}{900} \times 10000
$$

$B p$ is total actual biomass (ton ha- ${ }^{-1}$ ), $B k$ is dry biomass (ton tree ${ }^{-1}$ ) from Equation (9), 900 is plot area $\left(\mathrm{m}^{2}\right)$, and $n$ is number (trees plot $\left.{ }^{-1}\right)$. The actual carbon $\left(C_{a c t}\right.$, ton $\mathrm{ha}^{-1}$ ) stock in oil palm and rubber plants was calculated using Equation (11).

$$
C_{a c t}=B p \times C \text {. Organic }
$$

The C.Organic is the same as Equation (8). Then we performed paired t-test between the estimated carbon stock $\left(C_{e s t}\right)$ and the actual carbon stock $\left(C_{a c t}\right)$ to validate the result. Data image analysis was performed in ArcGIS platform, whereas statistical analysis was done in Minitab 17.1

\section{RESULTS AND DISCUSSIONS}

\section{Changes in Carbon Stocks}

Land-use and land-use changes will affect the dynamics of carbon stock in a land. Carbon stock is also influenced by the density of vegetation. In our study area, the carbon stock varied between land-uses and planting year of oil palm. Changes in carbon stocks in
Kebun Melati based on actual measurement and estimation are presented in Figure 1.

Based on our measurements, the finding showed that there was an increase of carbon stock from 18.43 ton ha $\mathrm{ha}^{-1}$ in 2000 to 22.52 ton ha ${ }^{-1}$ in 2009 . Then it became almost double (mean $=41.47$ ton ha-1) in 2019 . The increased carbon stock from 2000 to 2009 occurred due to the conversion of rubber to oil palm. Biomass from oil palm was typically higher than that of rubber. Other factor influencing low carbon stock in rubber was plant population. The low population of rubber plant at the beginning of the year 2000 led to a change in commodities from rubber to oil palm. In 2000, the population of rubber was $69.73 \%$, whereas in 2009 the oil palm population was dominant (75.91\%). The high carbon stock in 2019 was corresponded to growing and development of oil palm.

With increasing age of oil palm, the biomass automatically increases. The bigger the plant biomass is, the higher the potential carbon stock will be. Our statistical analysis suggested that the outcome of estimated carbon stock was reliable as indicated by small $p$-value (0.472). Figure 2 a shows the relationship between the estimated carbon stock ( $y$-axis) and the actual carbon stock ( $x$-axis) from field measurement.

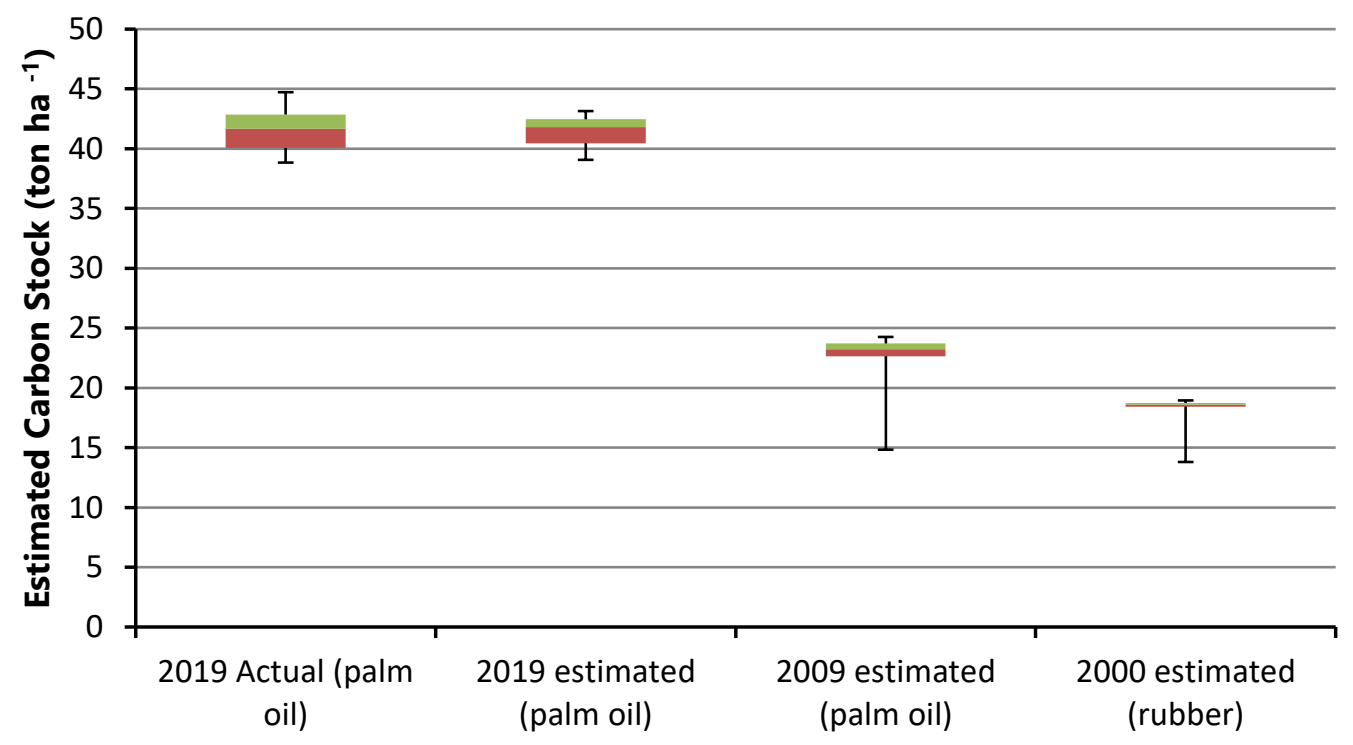

Planting Year

Figure 1 Potential estimats of carbon stock (ton ha-1) in oil palm and rubber

Distribution data presented in Figure $2 \mathrm{a}$ indicated that there is no heteroscedasticity between the estimated carbon stock and the actual carbon stock in 2019. Most of data tend to close to the 1:1 line, indicating that the estimated value is getting closer to the actual value. Heteroscedasticity is one of the regression model deviations, where there is an inequality of variance from one residual observation to another (Ghozali, 2016).
The high carbon stock is associated with the intensified photosynthetic activity and a good response to environmental conditions. A well-managed oil palm can absorb more carbon than upland secondary forest plants. For instance, the oil palm, which is more than 10 -year old is able to store carbon stock about 79.83 ton $\mathrm{ha}^{-1}$ (Rachdian and Setiawan, 2018).

The growth and development of oil palm are associated with the increasing rate of plant photosyn- 
thesis. According to Moonmoon et al., (2017), photosynthesis will affect plant dry weight. Dry weight is part of the efficiency of absorption and utilization of solar radiation available during the planting season. The increased dry weight indicates a growing of radiation use efficiency by plant canopy, which leads to the rise of assimilate.

The increase of carbon stock depends on the nitrogen availability within plant biomass. Nitrogen fertilizers potentially raise the following morphology of oil palm: plant height, midrib length, stem circumference, and leaf area (Albari, 2018). The changes in carbon stocks are closely related to the changes in land-use and land cover per period of time in an oil palm. The denser the vegetation, the greater the potential for carbon stock.

\section{Rainfall and Carbon Biomass}

Climate and weather are the main factors controlling growth and development of oil palm. Rainfall determine not only growth and development, but it affects the production of oil palm as well (Eycott et al.,
2019). In other hand, plant growth and development will affect carbon uptake by plants (Rosenani et al., 2016). The relation between the average rainfall and the carbon stock of oil palm is presented in Figure $2 b$.

Figure $2 b$ indicates that there is a linear relationship between average monthly rainfall (August 1998-July 2000, August 2007-July 2009, and August 2017-July 2019) and the actual carbon stock (50 samples). An increased rainfall will contribute to the high carbon stock within oil palm. Previous research revealed that rainfall affects the amount and quality of organic residues produced (Shi, 2020). In addition, rainfall influences the rate of decomposition of organic matter (Chen et al., 2016). Generally, high rainfall is associated with relatively high vegetation growth, which affects the increase in input and accumulation of organic matter. One research pointed out that carbon density was significantly higher in areas with monthly rainfall $>500 \mathrm{~mm}$ compared to that of monthly rainfall $<500 \mathrm{~mm}$ (Jeong et al., 2017). A linear correlation between plant biomass and carbon stock is presented

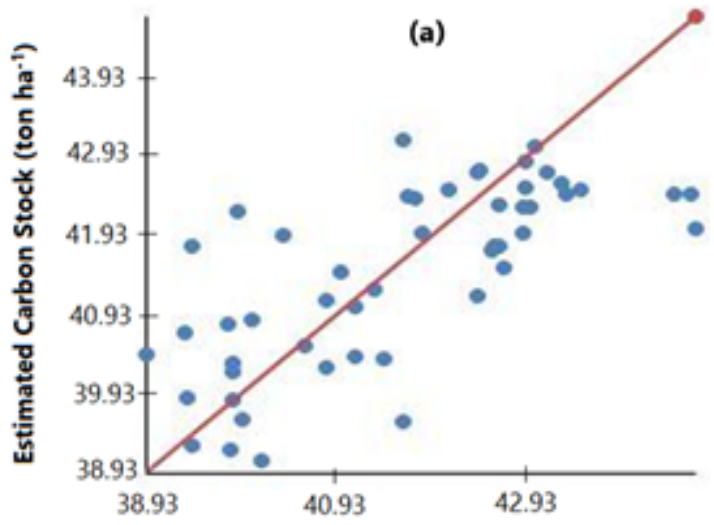

Actual Carbon Stock (ton ha-1)

(c)

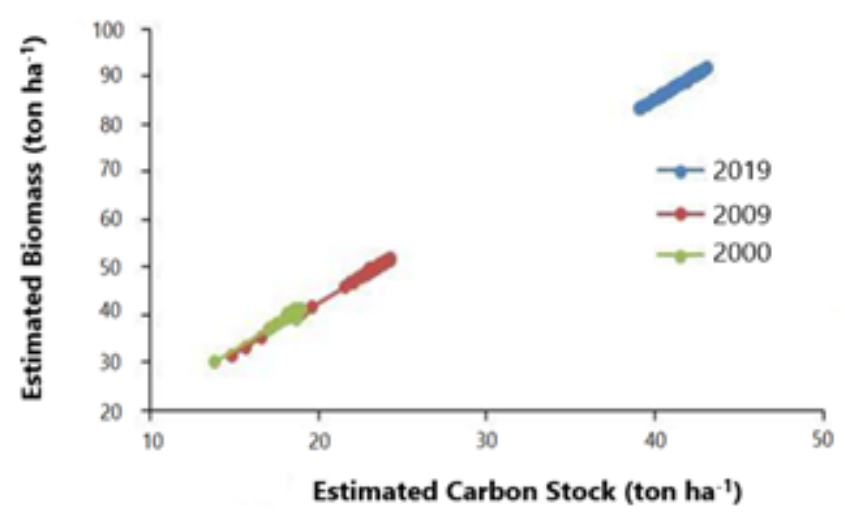

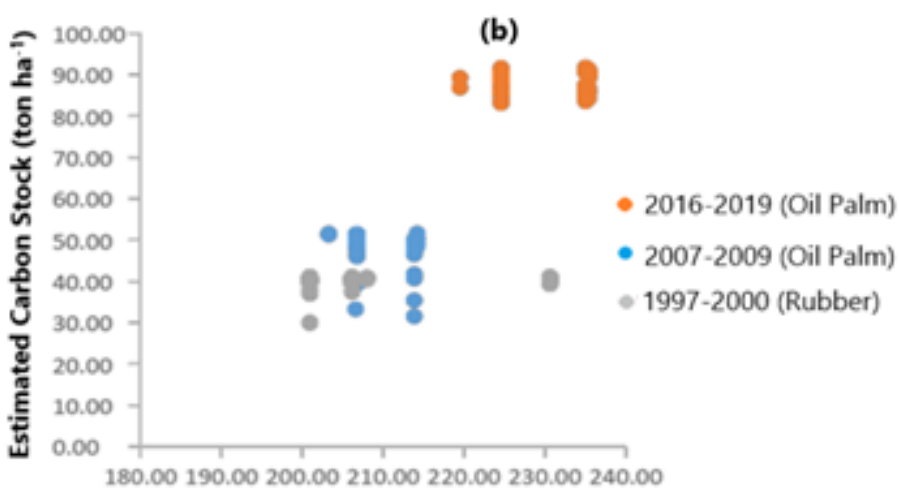

Average Rainfall (mm month ${ }^{-1}$ )

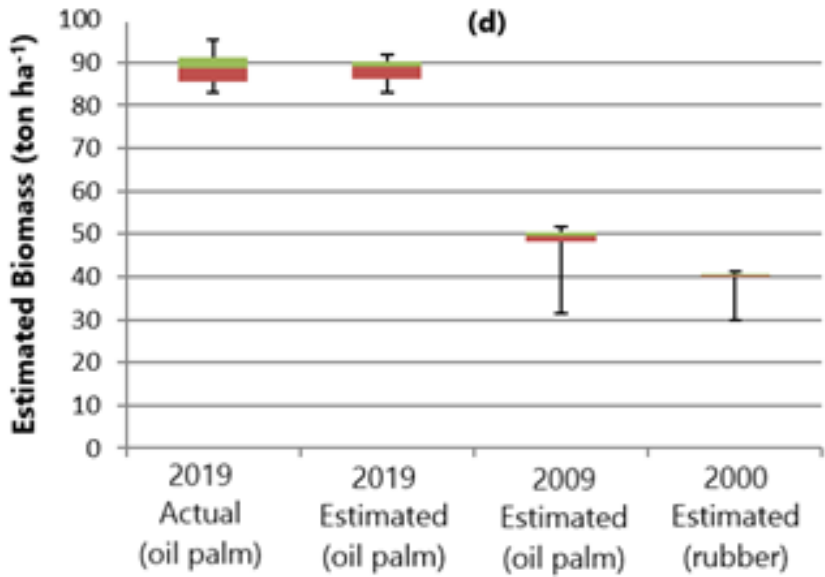

Figure 2 (a) Estimated and actual carbon stock in 2019 (ton ha-1), (b) monthly rainfall and estimated carbon stock, (c) biomass and carbon stock of estimated sample yields, and (d) biomass alleged crop (ton ha-1).

in Figure 2c. It shows that plant biomass will have an effect on the carbon stock absorbed by plants. If the plant biomass increases, the plant carbon stock will rise.

The existing plants in 2009 and 2019 were dominated by oil palm, whereas in 2000 it was a rubber plant. Therefore, the plant biomass in 2009 and 2019 was higher than in 2000 . The less biomass in 2000 was caused by the low population of rubber plants. The actual and estimated plant biomass in Kebun Melati were presented in Figure $2 \mathrm{~d}$. There was an increase in 
the average plant biomass from 40.03 ton ha-1 in 2000, to 47.94 ton ha ${ }^{-1}$ in 2009 , then almost double (88.23 ton $\mathrm{ha}^{-1}$ ) in 2019.

The potential carbon stock of oil palm plants in Kebun Melati for 2019 (age = 19 years old) was 41.47 ton $\mathrm{ha}^{-1}$ and for 2009 (age $=9$ years old) was 22.52 ton $\mathrm{ha}^{-1}$. The finding was similar to previous research (Purba et al., 2019), which stated that the carbon stock of oil palm at 10 years old was 24.91 ton ha-1.

Average monthly rainfall in Kebun Melati for 2000 was $206 \mathrm{~mm} \mathrm{month}^{-1}$. In 2009 and 2019, the monthly rainfall was higher than in 2000, namely 212 $\mathrm{mm}$ and $227 \mathrm{~mm}$, respectively. High rainfall triggered great absorption of carbon by oil palm ecosystem. This result was in line with previous research in India (Rakesh et al., 2020).

Rainfall has a direct impact on growth and development of oil palm. Period of low rainfall affected biomass of oil palm by decreasing the number of leaves and female flowers (Agustiana et al., 2019). Other research confirmed that low rainfall has caused disturbance on oil palm leaves (Darlan et al., 2016). They also reported that prolonged low rainfall leads to drought stress, which declined oil palm productivity also reported in Southern Sumatra. Technical measures that can minimize the impact of drought stress are practically research challenges, such as application of proper postdrought cultivation techniques, fertilization, system development, and soil and water conservation.

\section{CONCLUSIONS}

Oil palm stored much more biomass compared to rubber. Carbon stock for 9 years old of oil palm was 22.52 ton $\mathrm{ha}^{-1}$, and 41.47 ton ha ${ }^{-1}$ for 19 years old. Population density influences how much carbon that can be stored in ecosystem. Rainfall also affected the capability of oil palm ecosystem to absorb carbon. High rainfall means that more carbon will be stored.

\section{ACKNOWLEDGEMENT}

The authors would like to thanks PT Nusantara Plantation 2 Districk Kebun Melati, North Sumatra Province which has given permission for a place to do research and the field officers for their assistance and cooperation. The author gives thanks to friends who cannot be mentioned one by one for their kind help.

\section{REFERENCES}

Agus, F., Gunarso, P., Sahardjo, B.H., Harris, N., van Noordwijk, M., Killeen, T.J., 2013. Historical CO2 emissions from land use and land use change from the oil palm industry in Indonesia,
Malaysia and Papua New Guinea. Roundtable on Sustainable Palm Oil, Kuala Lumpur.

Agustiana, S., Wandri, R., Asmono, D., 2019. Performa Tanaman Kelapa Sawit pada Musim Kering di Sumatera Selatan; Pengaruh Defisit Air terhadap Fenologi Tanaman. Presented at the Seminar Nasional Lahan Suboptimal, pp. 67-73.

Albari, J., 2018. Peranan Pupuk Nitrogen dan Fosfor pada Tanaman Kelapa Sawit (Elaeis guineensis Jacq.) Belum Menghasilkan Umur Tiga Tahun. Buletin Agrohorti 6, 42-49.

Amliana, D.R., Prasetyo, Y., Sukmono, A., 2016. Analisis Perbandingan Nilai NDVI Landsat 7 dan Landsat 8 Pada Kelas Tutupan Lahan (Studi Kasus: Kota Semarang, Jawa Tengah). Jurnal Geodesi Undip 5, 264-274.

Arneth, A., Sitch, S., Pongratz, J., Stocker, B.D., Ciais, P., Poulter, B., Bayer, A.D., Bondeau, A., Calle, L., Chini, L.P., 2017. Historical carbon dioxide emissions caused by land-use changes are possibly larger than assumed. Nature Geoscience 10, 79-84.

Austin, K.G., Lee, M.E., Clark, C., Forester, B.R., Urban, D.L., White, L., Kasibhatla, P.S., Poulsen, J.R., 2017. An assessment of high carbon stock and high conservation value approaches to sustainable oil palm cultivation in Gabon. Environ. Res. Lett. 12, 014005. https://doi.org/10.1088/1748-9326/aa5437

Avdan, U., Jovanovska, G., 2016. Algorithm for Automated Mapping of Land Surface Temperature Using LANDSAT 8 Satellite Data. Journal of Sensors 2016, 1480307. https://doi.org/10.1155/2016/1480307

Azham, Z., 2015. Estimasi Cadangan Karbon Pada Tutupan Lahan Hutan Sekunder, Semak dan Belukar di Kota Samarinda. Agrifor 14, 325-338.

Behera, S.K., Sahu, N., Mishra, A.K., Bargali, S.S., Behera, M.D., Tuli, R., 2017. Aboveground biomass and carbon stock assessment in Indian tropical deciduous forest and relationship with stand structural attributes. Ecological Engineering 99, 513-524.

Besar, N.A., Suardi, H., Phua, M.-H., James, D., Mokhtar, M.B., Ahmed, M.F., 2020. Carbon Stock and Sequestration Potential of an Agroforestry System in Sabah, Malaysia. Forests 11, 210. https://doi.org/10.3390/f11020210

BPS, 2018a. Statistik Kelapa Sawit Indonesia 2017. Badan Pusat Statistik, Indonesia.

BPS, 2018b. Statistik Karet Indonesia 2018. Badan Pusat Statistik, Jakarta.

Burton, M.E., Poulsen, J.R., Lee, M.E., Medjibe, V.P., Stewart, C.G., Venkataraman, A., White, L.J., 
2017. Reducing carbon emissions from forest conversion for oil palm agriculture in Gabon. Conservation Letters 10, 297-307.

Cao, R., Chen, Y., Shen, M., Chen, J., Zhou, J., Wang, C., Yang, W., 2018. A simple method to improve the quality of NDVI time-series data by integrating spatiotemporal information with the Savitzky-Golay filter. Remote Sensing of Environment 217, 244-257. https://doi.org/10.1016/j.rse.2018.08.022

Carlson, K.M., Curran, L.M., Ratnasari, D., Pittman, A.M., Soares-Filho, B.S., Asner, G.P., Trigg, S.N., Gaveau, D.A., Lawrence, D., Rodrigues, H.O., 2012. Committed carbon emissions, deforestation, and community land conversion from oil palm plantation expansion in West Kalimantan, Indonesia. Proceedings of the National Academy of Sciences 109, 7559-7564.

Chen, X., Zhang, D., Liang, G., Qiu, Q., Liu, J., Zhou, G., Liu, S., Chu, G., Yan, J., 2016. Effects of precipitation on soil organic carbon fractions in three subtropical forests in southern China. Journal of Plant Ecology 9, 10-19.

Chu, H., Venevsky, S., Wu, C., Wang, M., 2019. NDVIbased vegetation dynamics and its response to climate changes at Amur-Heilongjiang River Basin from 1982 to 2015. Science of The Total Environment 650, 2051-2062. https://doi.org/10.1016/j.scitotenv.2018.09.11 5

Cook, S., Whelan, M.J., Evans, C.D., Gauci, V., Peacock, M., Garnett, M.H., Kho, L.K., Teh, Y.A., Page, S.E., 2018. Fluvial organic carbon fluxes from oil palm plantations on tropical peatland. Biogeosciences 15, 7435-7450. https://doi.org/10.5194/bg-15-7435-2018

Darlan, N.H., Pradiko, I., Siregar, H.H., 2016. Dampak El Nino 2015 terhadap Performa Tanaman Kelapa Sawit di Bagian Selatan Sumatera (Effect of El Nino 2015 on Oil Palm Performance in Southeastern Part of Sumatera). Jurnal Tanah dan Iklim 40, 113-120. https://doi.org/10.21082/jti.v40n2.2016.113120

Darlita, R.D.R., Joy, B., Sudirja, R., 2017. Analisis beberapa sifat kimia tanah terhadap peningkatan produksi Kelapa Sawit pada tanah pasir di Perkebunan Kelapa Sawit Selangkun. Agrikultura 28.

Dewanti, R., Sari, I.L., 2017. A two-steps radiometric correction of Spot-4 multispectral and multitemporal for seamless mosaic in Central Kalimantan. IJReSES 11, 97-104.
Duan, T., Chapman, S.C., Guo, Y., Zheng, B., 2017. Dynamic monitoring of NDVI in wheat agronomy and breeding trials using an unmanned aerial vehicle. Field Crops Research 210, $71-80$. https://doi.org/10.1016/j.fcr.2017.05.025

Eycott, A.E., Advento, A.D., Waters, H.S., Luke, S.H., Aryawan, A.A.K., Hood, A.S., Naim, M., Ps, S., Pujianto, Purnomo, D., Rambe, T.D.S., Soeprapto, Suhardi, Tarigan, R.S., Wahyuningsih, R., Widodo, R.H., Caliman, J.-P., Snaddon, J.L., Foster, W.A., Turner, E.C., 2019. Resilience of ecological functions to drought in an oil palm agroecosystem. Environ. Res. Commun. 1 , 101004. https://doi.org/10.1088/2515-7620/ab48da

Finstad, K., van Straaten, O., Veldkamp, E., McFarlane, K., 2020. Soil carbon dynamics following land use changes and conversion to oil palm plantations in tropical lowlands inferred from radiocarbon. Global Biogeochemical Cycles 34, e2019GB006461.

Ghozali, I., 2016. Aplikasi analisis multivariete dengan program IBM SPSS 23, VIII. ed. Universitas Diponegoro Press, Semarang.

Gul, M., Kotak, Y., Muneer, T., Ivanova, S., 2018. Enhancement of albedo for solar energy gain with particular emphasis on overcast skies. Energies 11, 2881.

Guzha, A., Rufino, M.C., Okoth, S., Jacobs, S., Nóbrega, R., 2018. Impacts of land use and land cover change on surface runoff, discharge and low flows: Evidence from East Africa. Journal of Hydrology: Regional Studies 15, 49-67.

Ishikura, K., Hirano, T., Okimoto, Y., Hirata, R., Kiew, F., Melling, L., Aeries, E.B., San Lo, K., Musin, K.K., Waili, J.W., 2018. Soil carbon dioxide emissions due to oxidative peat decomposition in an oil palm plantation on tropical peat. Agriculture, ecosystems \& environment 254, 202-212.

Jeong, S.-H., Eom, J.-Y., Lee, J., Lee, J.-S., 2017. Effect of rainfall events on soil carbon flux in mountain pastures. Journal of Ecology and Environment $41,1-8$.

Khoon, K., Rumpang, E., Kamarudin, N., Harun, M.H., 2019. Quantifying total carbon stock of mature oil palm. Journal of Oil Palm Research 31, 521 527.

Kii, M.I., June, T., Santikayasa, I.P., 2020. Dynamics Modeling of CO2 in Oil Palm. Agromet 34, $42-$ 54.

Manoli, G., Meijide, A., Huth, N., Knohl, A., Kosugi, Y., Burlando, P., Ghazoul, J., Fatichi, S., 2018. Ecohydrological changes after tropical forest 
conversion to oil palm. Environ. Res. Lett. 13, 064035. https://doi.org/10.1088/17489326/aac54e

Meijide, A., de la Rua, C., Guillaume, T., Röll, A., Hassler, E., Stiegler, C., Tjoa, A., June, T., Corre, M.D., Veldkamp, E., 2020. Measured greenhouse gas budgets challenge emission savings from palm-oil biodiesel. Nature communications 11, 1-11.

Mohidin, H., Man, S., Hanafi, M.M., Rufai, S., Idris, J., Fonguimgo, T., Idris, A.S., Rafii, Y.M., 2019. Optimum levels of $\mathrm{N}, \mathrm{P}$, and $\mathrm{K}$ nutrition for oil palm seedlings grown in tropical peat soil. Journal of Plant Nutrition 42, 1461-1471.

Moonmoon, S., Fakir, M., Islam, M., 2017. Effect of drought stress on grain dry weight, photosynthesis and chlorophyll in six rice genotypes. Sch. J. Agric. Vet. Sci 4, 13-17.

Paterson, R.R.M., Kumar, L., Taylor, S., Lima, N., 2015. Future climate effects on suitability for growth of oil palms in Malaysia and Indonesia. Scientific reports 5, 14457.

Perez, R., 2017. Analyzing and modelling the genetic variability of aerial architecture and light interception of oil palm (Elaeis guineensis Jacq). Montpellier, SupAgro.

Pulhin, F.B., Lasco, R.D., Urquiola, J.P., 2014. Carbon sequestration potential of oil palm in Bohol, Philippines. Ecosystems and Development Journal 4.

Purba, I., Siagian, M., Erna, M., 2019. Kandungan Karbon d Perkebunan Kelapa Sawit Pada Lahan Gambut di Desa Berumbung Baru Kecamatan Dayun Kabupaten Siak Provinsi Riau. Jurnal Ilmu Lingkungan 13, 90-96.

Rachdian, A., Setiawan, Y., 2018. The Estimation of Oil Palm Carbon Stock in Sembilang Dangku Landscape, South Sumatra. Media Konservasi 23, 153-161.

Rahaju, S., 2008. Kajian Perolehan Karbon Sebagai Dampak Intervensi Kasus: Eks-plg Blok a, Mentangai, Kalimantan Tengah (carbon Result Study as Intervention Impact, Case: Eks-plg Block a, Mentangai, Central Borneo). Agromet 22, 1-12.

Rakesh, S., Davamani, V., Kamaludeen, S.P., Maragatham, S., Lakshmanan, A., Parameswari, E., Velmurugan, M., 2020. Carbon sequestration potential of oil palm plantations in Tamil Nadu regimes, India. International Research Journal of Pure and Applied Chemistry 7-17.

Rosenani, A.B., Rovica, R., Cheah, P.M., Lim, C.T., 2016. Growth Performance and Nutrient Uptake of Oil Palm Seedling in Prenursery Stage as Influenced by Oil Palm Waste Compost in Growing Media. International Journal of Agronomy 2016, 6930735. https://doi.org/10.1155/2016/6930735

Shi, W.-Y., 2020. Soil Carbon Biogeochemistry in Arid and Semiarid Forests, in: Zhu, X.-C. (Ed.), Kai-Bo Wang (Tran.), Applied Geochemistry with Case Studies on Geological Formations, Exploration Techniques and Environmental Issues. IntechOpen, Rijeka, p. Ch. 3. https://doi.org/10.5772/intechopen.87951

Siswoko, E., Mulyadi, A., Thamrin, T., Bahruddin, B., 2017 Pendugaan kandungan karbon limbah batang pohon kelapa sawit peremajaan kebun di Provinsi Riau. Jurnal Ilmu Lingkungan 11, 154163.

Srinivas, K., Sundarapandian, S., 2019. Biomass and carbon stocks of trees in tropical dry forest of East Godavari region, Andhra Pradesh, India. Geology, Ecology, and Landscapes 3, 114-122.

Supriadi, H., 2012. Peran Tanaman Karet dalam Mitigasi Perubahan Iklim. Bul. RISTRI 3, 12.

Toru, T., Kibret, K., 2019. Carbon stock under major land use/land cover types of Hades sub-watershed, eastern Ethiopia. Carbon balance and management 14, 7.

Twele, A., Erasmi, S., Kappas, M., 2008. Spatially explicit estimation of leaf area index using EO-1 Hyperion and Landsat ETM+ data: implications of spectral bandwidth and shortwave infrared data on prediction accuracy in a tropical montane environment. GIScience \& Remote Sensing 45, 229-248.

USGS, 2016. Landsat 8 (L8) Data User Handbook version 2.0.

Uttaruk, Y., Laosuwan, T., 2016. Remote sensing based vegetation indices for estimating above ground carbon sequestration in orchards. Poljoprivreda i Sumarstvo 62, 193.

Yulianto, Setiadi, D., Sulistijorini, 2016. Estimating stored carbon stock in oil palm (Elaeis guineensis Jacq.) plantation by age group in PT. Daria Dharma Pratama Plantation Bengkulu Indonesia. Int. J. Agr. Agri. Res. 8, 81-86. 